\title{
Aktivitas Tabligh Majelis Ta'lim Tuli Indonesia
}

\author{
Anita Khuzaimah, Sitty Sumijati, \& Asep Shodiqin \\ Jurusan Komunikasi dan Penyiaran Islam, Fakultas Dakwah dan Komunikasi, \\ UIN Sunan Gunung Djati, Bandung \\ *Email : anitakhuraimah@gmail.com
}

\begin{abstract}
Tabligh Islam should be submitted to every people, even for the deaf. A deaf need to gain knowledge about religion even in the midst of its limitations. Deaf need a container and media that can be used as a place to increase religious knowledge, such as that done by Majelis Ta'lim Tuli Indonesia (MTTI) in conveying the teachings of Islam to other fellow deaf. The purpose of this study to find out how tabligh applied by MTTI through the elements contained in existing activities on MTTI, such as materials, methods and media tabligh used on MTTI. Researchers use descriptive analysis method using qualitative approach. The data used through interviews, observations, notes, and survey books and supported by the relevant documentation in this study. The results showed that MTTI delivered a tabligh message based on the elements contained in its own tabligh activities. This tabligh includes the presentation of materials, methods, and media used. Based on these findings, it can be concluded that Tabligh in MTTI to its congregation can add to the motivation as well as provide religious knowledge that has not been owned. The right method and a relaxed but relaxed teaching method can make MTTI congregation feel comfortable and understanding with what is delivered, so MTTI congregation is also eager to follow the activity in MTTI.
\end{abstract}

Keywords: tabligh; deaf; disability

\begin{abstract}
ABSTRAK
Tabligh Islam perlu disampaikan kepada setiap umat, bagi tunarungu sekalipun. Seorang tunarungu perlu mendapatkan pengetahuan tentang agama walau di tengah keterbatasan yang dimiliki. Tunarungu tentunya memerlukan wadah dan media yang bisa dijadikan tempat untuk menambah pengetahuan agama, seperti yang dilakukan Majelis Ta'lim Tuli Indonesia (MTTI) dalam menyampaikan ajaran Islam kepada sesama tunarungu lainnya.Tujuan penelitian ini untuk mengetahui bagaimana tabligh yang diterapkan oleh MTTI melalui unsur-unsur yang terkandung dalam kegiatan yang ada di MTTI, seperti materi, metode dan media tabligh yang digunakan di MTTI. Peneliti menggunakan metode analisis deskriptif dengan menggunakan pendekatan kualitatif. Data-data yang digunakan melalui wawancara, observasi, mencatat, dan book survei serta didukung oleh dokumentasi yang relevan dalam penelitian ini. Hasil penelitian menunjukan bahwa MT'TI menyampaikan pesan tabligh berdasarkan dengan unsur-unsur yang
\end{abstract}


terkandung dalam kegiatan tabligh tersendiri. Tabligh ini meliputi penyajian materi, metode, serta media yang digunakan. Berdasarkan temuan ini, dapat disimpulkan bahwa Tabligh di MT'TI terhadap jamaahnya dapat menambah motivasi serta memberikan pengetahuan agama yang belum dimiliki. Metode yang tepat dan cara mengajar yang tegas tapi santai mampu membuat jamaah MT'TI merasa nyaman dan mengerti dengan apa yang disampaikan, sehingga jamaah MT'TI pun semangat untuk mengikuti kegiatan di MT'TI.

Kata Kunci : tabligh; tuli; disabilitas

\section{PENDAHULUAN}

Aktivitas tabligh harus dilakukan ke seluruh lapisan umat. Termasuk kaum tunarungu yang memiliki keterbatasan fisik. Karena semua umat muslim berhak menerima ajaran agama Islam. Oleh karena itu, sudah menjadi kewajiban kita sebagai umat muslim untuk memberikan wadah untuk kaum tunarungu belajar agama Islam. Hal ini serupa dengan MT'TI, yaitu dengan memberikan pengajaran terhadap kaum tunarungu tentang agama Islam dengan metode-metode yang sesuai dengan kemampuan tunarungu. Kata tabligh merupakan bahasa Arab, yang berasal dari akar kata: ballagha, yubllighu, tablighan, yang berarti menyampaikan. Tabligh adalah kata kerja transsitif, yang berarti membuat seseorang, menyampaikan atau melaporkan (Sukayat, 2009: 87).

Dalam konsep Islam, tabligh merupakan salah satu perintah yang dibebankan kepada para utusan-Nya. Bahkan diantara kesempurnaan Muhammas saw. adalah beliau memiliki empat sifat, yaitu: shidiq, amanah, fathonah, dan tabligh.

Tunarungu adalah mereka yang mengalami gangguan pada organ pendengaran sehingga mengakibatkan ketidakmampuan mendengar, mulai dari tingkatan yang ringan sampai yang berat sekali yang dikasifikasikan ke dalam kategori tuli (deaf) dan kurang dengar (hard of hearing). Halahan dan Kauffman (1991: 266) mengemukakan bahwa orang yang tuli adalah orang yang mengalami ketidakmampuan mendengar sehingga mengalami hambatan dalam memproses informasi bahasa melalui pendengarannya dengan atau tanpa menggunakan alat bantu dengar (hearing aid).

Sama halnya dengan tabligh, tabligh juga merupakan bagian dari dakwah yaitu untuk menyampaikan ajaran-ajaran Islam kepada umat manusia. Tidak membeda-bedakan semua sama, semua berhak mendapatkan pendidikan ataupun ajaran Islam.

Meskipun begitu, sampai saat ini keberadaan difabel masih terdiskriminasi, baik secara struktural maupun kultural. Perihal tersebut dapat dibuktikan bahwa masih banyaknya peraturan dalam sistem negara ini yang menghalangi mereka untuk memperoleh hak-hak yang sama dengan masyarakat penyediaan layanan pendidikan (Aziz, 2014: 46-47).

Padahal peraturan-peraturan standar tentang kesamaan kesempatan bagi 
penyandang cacat apapun tertuang dalam Undang-Undang No. 4 tahun 1997 tentang penyandang cacat bahwa setiap penyandang cacat mempunyai hak dan kewajiban yang sama atas pendidikan, pekerjaan, perlakuan yang sama termasuk layanan kesehatan. Tampaknya, pemerintah belum memberikan layanan dan pengayoman secara maksimal terhadap warga difabel (Aziz, 2014: 47).

Dalam Islam orang-orang yang memiliki keterbatasan telah mendapatkan perhatian khusus, yang menyatakan bahwa mereka tidak memiliki perbedaan dengan mereka yang terlihat tidak memiliki keterbatasan.

Berbicara tentang komunikasi berarti kitapun berbicara tentang bahasa. Sejarah umat manusia di muka bumi ini telah mencatat bahwa umat manusia di muka bumi telah mencatat bahwa tidak ada satu bangsapun yang tidak mempunyai bahasa. Hanya dengan bahsalah manusia berkomunikasi dan mempertukarkan pikiran, perasaan, menerima dan memahami perbuatan satu sama yang lain (Liliweri, 1994: 1)

Cara terbaik dalam berkomunikasi adalah berbicara. Namun beda halnya berkomunikasi dengan penyandang tunarungu. berkomunikasi dengan penyandang tunarungu tidak hanya sekedar berbicara. Dalam situasi ini berkomunikasi dengan penyandang tunarungu memiliki masalah, karena penyandang tunarungu tidak dapat mendengar dan berbicara. Oleh karena itu ada cara yang tepat untuk berkomunikasi dengan penyandang tunarungu yaitu dengan komunikasi nonverbal.

Komunikasi nonverbal acapkali dipergunakan untuk menggambarkan perasaan, emosi. Jika pesan yang anda terima melalui sistem verbal tidak menunjukkan kekuatan pesan maka anda dapat menerima tanda-tanda nonverbal lainnya sebagai pendukung (Liliweri, 1994: 89).

Komunikasi nonverbal juga acapkali disebut: komunikasi tanpa kata (karena tidak dapat berkata-kata (Liliweri, 1994: 89). Para ahli komunikasi berpendapat bahwa jika anda diam, maka diamnya anda merupakan satu bentuk komunikasi antarpribadi. Diam juga merupakan kata-kata anda. Seseorang yang diam tidaklah sembarang diam, ia mungkin bertindak tepat (ata mungkin kurang tepat). Diam sama kuatnya dengan pesan-pesan verbal yang diucapkan dalam kata-kata. Dengan berdiam diri maka anda telah berkomunikasi secara nonverbal. Terkadang mungkin tanpa suara, tanpa kata, atau mungkin dengan gerakan tubuh/anggota tubuh, anda tetap melakukan komunikasi nonverbal. Meskipun anda berdiam diri namun pernyataan wajah anda pun bisa dengan makna tertentu terhadap pribadi dan memberikan pesan dengan orang lain (Liliweri, 1994: 88).

Tabligh merupakan suatu kegiatan yang mengedepankan teknik berbicara ataupun menulis. Tabligh merupakan penyampaian pesan. Pelakunya disebut mubaligh. Dalam konsep Islam, tabligh merupakan salah satu perintah yang dibebankan kepada para utusan-Nya. Bahkan di antara kesempurnaan karakteristik Muhammad saw adalah shidadiq, amanah, fathonah, dan tabligh. Sifat tabligh yang dimiliki Muhammad saw. dalam pandangan ulama as-'Ariyah merupakan sifat wajib yang harus ada pada Rasulullah, karena rasulullah saw. sebagai penerima wahyu dari Allah Swt. yang harus disampaikan kembali kepada 
umatnya.

Di Indonesia gerakan tabligh terhadap tunarungu sudah mulai berkembang. Dimulai dari jamaah Pakistan yang singgah dari masjid ke masjid di Indonesia hingga akhirnya para disabilitas tuna rungu Indonesia telah berhasil berhasil berdiri sendiri meneruskan jalan tabligh bagi sesama mereka.

Salah satunya adalah Majelis Ta'lim Tuli Indonesia. MT'TI ini adalah Majelis Ta'lim yang di khususkan untuk kaum tuli. Di awali dari kerisauan sebagai rekan tuli muslim, ketika melihat masih banyaknya sesama rekan tuli muslim di Indonesia yang tidak memahami nilai-nilai Agama Islam. Bahkan kebanyakan mereka tidak mengenal siapa itu Allah SWT dan Nabi Muhammad SAW. Berangkat dari itu, maka beberapa tuli muslim di Jabodetabek membentuk sebuah yayasan sebagai sarana pembelajaran Agama Islam bagi kaum tuli Indonesia.

MT'TI merupakan Yayasan yang diselenggarakan untuk kegiatan-kegiatan keagamaan seperti pengajian. Walaupun Yayasan MTTI ini dikhususkan untuk kaum tuli, namum ada beberapa pengurus yang bukan dari kaum tuli. Mereka menyiarkan agama Islam kepada kaum tuli dengan menggunakan bahasa isyarat. Menurutnya menyiarkan agama Islam itu penting. Karena semua umat muslim wajib beribadah kepada Allah, tidak terkecuali kaum tuli yang memiliki keterbatasan fisik.

Majelis Ta'lim 'Tuli Indonesia (MTTI) merupakan salah satu yayasan yang didirikan berlatar belakang dari keprihatin terhadap kondisi umat Tuli Islam di Indonesia yang masih saja dalam kondisi yang belum exis, mandiri dan menjadi solusi negeri ini, apalagi jika kita menengok kondisi kaum Tuli yang kian hari kian banyak yang sudah tak lagi menunjukkan produktif sehingga makin jauh dari kebanggaan terhadap bangsa dan agamanya, gelombang modernisasi dengan globalisasinya kian memberikan ruang yang amat luas pada generasi negeri dan umat ini untuk mengakses banyak hal dari luar, yang sayangnya ternyata lebih banyak pengaruh negative yang diikuti oleh komunitas tuli Islam, dari pada efek positif yang diteladani. Hal inilah yang mendasari didirikannya Yayasan Majlis Ta'lim Tuli Indonesia. Majelis Ta'lim Tuli Indonesia (MT'TI) ini berdiri pada 21 september 2016. Majelis Ta'lim Tuli Indonesia (MTTI) ini berdiri dengan cara mengumpulkan orang-orang tuli lalu mereka mengumpulkan dana. Awalnya Majlis Ta'lim Tuli Indonesia (MT'TI) hanya terdiri dari 15 orang. Dan kemudian, mereka mengajak kaum tunarungu untuk bergabung dengan cara mulut ke mulut, sosial media dan sebagainya. Sehingga selama setahun ini sudah terkumpul 200 anggota.

Permasalahan ini diambil karena di zaman sekarang untuk penderita di disabilitas, seperti kaum tuli memiliki banyak kendala dalam mempelajari agama. Kaum tuli terhalang oleh media dan fasilitas yang bisa digunakan untuk mempelajari agama. Kendala yang terjadi menyebabkan seorang tuli sulit untuk menyerap pelajaran agama yang disampaikan.

Dari latar belakang masalah tersebut dapat dirumuskan beberapa masalah dengan rumusan masalah: bagaimana materi tabligh yang disampaikan di Yayasan 
MT'TI terhadap jamaahnya? Bagaimana metode tabligh yang disampaikan MTTI terhadap jamaahnya? Bagaimana media tabligh yang disampaikan M'TI terhadap jamaahnya?

Dalam mengatasi permasalahan diatas tentunya MT'TI mempunyai cara khusus dalam menanganinya. Salah satunya dengan memberikan metode yang tepat dalam menyampaikan tabligh terhadap jamaah tuli. Dalam hal ini MT'TI menggunakan bahasa isyarat sebagai metode dalam menyampaikan tablighnya sekaligus menjadi cara komunikasi antar sesama di M'TI. MT'TI juga menggunakan cara yang tepat dalam menyampaikan ajaran islam, sehingga kita dapat mengetahui cara tabligh yang digunakan MT'TI dalam mengajar jamaah tuli di MT'TI. Dengan cara itulah tabligh bisa tersampaikan dengan baik.

Dalam menjalankan tugasnya untuk menyampaikan tabligh kepada kaum tuli di MT'TI banyak mubaligh yang berperan didalamnya. Di Majelis Ta'lim Tuli Indonesia terdapat 2 pengajar dan 16 orang pengurus yang mengajarkan kaum tunarungu tentang agama Islam. Dalam penyampaian tablighnya MTTI menggunakan bahasa isyarat. Namun, tidak semua penyandang tunarungu di MT'TI bisa berbahasa isyarat. Jadi, selain belajar tentang agama Islam, di MT'TI juga mengajarkan bagaimana berbahasa isyarat.

Di MTTI pengajian rutin dilakukan 2 minggu sekali. Pengajian dilakukan di masjid yang berbeda-beda setiap minggunya. Materi yang di ajarkan bermacammacam, seperti: adab-adab sunnah Nabi SAW, fiqih, belajar solat, belajar membaca Al-Qu'an da masih banyak lagi. Menurut data pengamatan peneliti terhadap jamaah yang mengikuti kegiatan tabligh di MT'TI, banyak manfaat yang bisa dirasakan dalam kegiatan pengajian tersebut. Tidak hanya menambah pengetahuan tentang pemahaman keagamaan tapi juga bisa menambah komunitas sesama tuli di Indonesia.

Metode yang digunakan dalam penelitian ini adalah metode deskriptif, dengan menganalisis hasil pengumpulan data melalui observasi dan wawancara dengan pihak-pihak terkait seperti, pengurus, pengajar dan anggota di MTTI.

\section{HASIL DAN PEMBAHASAN}

Penelitian ini dilakukan di MTTI, sebuah Majelis Ta'lim yang dikhusukan untuk jamaah tuli. Majelis Ta'lim Tuli Indonesia (MTTI) merupakan salah satu yayasan yang didirikan berlatar belakang dari keprihatin terhadap kondisi umat Tuli Islam di Indonesia yang masih saja dalam kondisi yang belum exis, mandiri dan menjadi solusi negeri ini, apalagi jika kita menengok kondisi kaum Tuli yang kian hari kian banyak yang sudah tak lagi menunjukkan produktif sehingga makin jauh dari kebanggaan terhadap bangsa dan agamanya.

Yayasan Majelis Ta'lim Tuli Indonesia berdiri pada 21 September 2016. Pendirinya merupakan sekawanan umat tuli muslim itu sendiri. Awal mula didirikannya Yayasan MT'TI ini, berawal dari kerisauan umat tuli muslim yang kebanyakan tidak paham agama Islam seperti apa. Dulu sebelum adanya MTTI, terdapat komunitas tuli yang didalamnya ada tuli Islam dan nasrani. Karena 
keterbatasannya ilmu yang dipunya, pernah suatu ketika tuli nasrani mengajak tuli Islam ke gereja dan disana tuli Islam merasa senang karena terdapat penerjemah bahasa isyarat dalam kegiatan di gereja sehingga mereka mengerti apa yang disampaikan. Beda halnya dengan ngaji ke mesjid-mesjid, kalau ngaji ke masjid mereka tidak paham apa yang disampaikan ustadznya karena belum adanya penerjemah Islam pada waktu itu. Dari situlah banyak tuli Islam yang imannya belum kuat masuk ke nasrani karena menurutnya lebih enak ke gereja karena sudah ada penerjemah bahasa isyarat.

Sampai pada akhirnya tuli Islam yang tidak ikut ke gereja bertemu dengan Ustadz Aprizar dan Ustadz Rama. Disana mereka menceritakan bagaimana kejadian teman-teman tuli lain yang ikut ke gereja. Menurut Ustadz Aprizar dan Ustadz Rama itu salah, namun teman-temaan tuli bingung karena ke masjid pun mereka tidak mendapatkan apa-apa, karena tidak paham apa yang disampaikan. Dari situlah Ustadz Aprizah dan Ustadz Rama di bantu teman-teman tuli lainnya mendirikan Yayasan MTTI.

Majelis Ta'lim Tuli Indonesia (MTTI) ini berdiri pada 21 september 2016. Majelis Ta'lim Tuli Indonesia (MTTI) ini berdiri dengan cara mengumpulkan orang-orang tuli lalu mereka mengumpulkan dana. Awalnya Majlis Ta'lim Tuli Indonesia (MT'TI) hanya terdiri dari 15 orang. Dan kemudian, mereka mengajak kaum tunarungu untuk bergabung dengan cara mulut ke mulut, sosial media dan sebagainya. Sehingga selama setahun ini sudah terkumpul 150 anggota.

Melihat kondisi objektif dari MT'TI, tabligh terhadap jamaah tuli memang tidak mudah. Kita harus bisa memahami kondisi mereka terlebih dahulu, karena dengan memahami kondisi mereka pesan tabligh yang MT'TI sampaikan bisa tersampaikan dengan baik.

Hasil penelitian ini menemukan bahwa untuk mengetahui tabligh yang di gunakan di MT'TI, kita juga harus melihat dari unsur-unsur tabligh itu sendiri, seperti yang peneliti bahas yaitu materi, metode, dan media. Tabligh yang dilakukan MT'TI dilihat dari aktivitas kegiatan MTTI itu sendiri yang mengandung aktvitas tabligh, seperti pengajian rutin, pesantren kilat, dan tabligh ke daerahdaerah. Dari setiap kegiatan yang dilakukan MTTI terdapat materi-materi yang sifatnya mengajak untuk meningkatkan pemahaman keagamaan terhadap jamaah di MT'TI.

Materi tabligh yang di sampaikan di MT'TI bersumber dari Al-Qur'an dan Hadits. Untuk penyusunan materi tablighnya MT'TI mengkaji nilai-nilai yang terdapat dalam Al-Qur'an dan Hadits. Materi yang disampaikan di MT'TI disesuaikan dengan kondisi jamaah tuli di MTTI. Materi yang diajarkan mulai dari tauhid sampai adab-adab Nabi Muhammad SAW. Untuk materi tauhid MT'TI mengenalkan tentang ketauhidan, karena jamaah MTTI awal mulanya belum paham dan mengenal siapa Tuhan mereka. Selain materi tauhid materi yang disampaikan lebih menekankan pada kehidupan sehari-hari. Seperti mengajarkan solat, cara-cara melakukan sesuatu sesuai di Al-Qur'an dan Hadist. Biasanya materi disampaikan mengikuti perbuatan Nabi Muhammad SAW, seperti tata cara 
makan, tata cara bertamu, tata cara wudhu dan lain-lain.

Setiap kegiatan tabligh keagamaan metode tabligh yang digunakan bermacam-macam. Menurut hasil analisis peneliti selama melakukan penelitian di MT'TI ada satu metode yang paling efektif untuk menunjang kegiatan tabligh di MTTI, yaitu metode syiar dengan syaria't. Yang dimaksud dengan syiar dengan isyarat adalah menyampaikan materi tabligh menggunakan bahasa isyarat.

Di MTTI terdapat ahli bahasa isyarat yang menemani sang penceramah untuk menjelaskan setiap pesan yang disampaikan. Adapula yang bertugas untuk mencatat beberapa hal penting di papan tulis.

Menurut Ustadz Farid, berdasarkan keterangan Tunarungu, alat bantu dengar tak berguna untuk orang tuli total. Hampir semua jamaah Tunarungu yang mengikuti pengajian mengaku alat bantu tak bisa menangkap suara penceramah seringkali terdengar seperti menggumam. Kebanyakan mereka menggunakan alat ini pun mengaku tak bisa terlalu lama menggunakannya karena bisa menyebabkan sakit kepala.

Sehingga, jalan terbaik menyiarkan agama kepada kaum tunarungu adalah dengan menggunakan bahasa isyarat. Menurut Ustadz Farid, berdasarkan penyataan konselor disabilitas Perserikatan Bangsa-Bangsa (PBB), orang tuli harus menerima informasi dengan bahasa yang mudah mereka pahami, yaitu isyarat. Dengan kata lain tidak boleh memaksa kaum tunarungu untuk bisa membaca gerak bibir. Dan melarang mereka berkomunikasi lewat isyarat.

Teman-teman tunarungu bilang, isyarat itu bahasa kami. Ketika disuruh baca bibir mereka berat, katanya. Di SLB Indonesia kurang pelajaran bahasa isyarat, ada mungkin abjad saja. Selebihnya, mereka suruh berbicara. Hal ini yang patut disayangkan, tunarungu muslim di Tanah Air belum memiliki pedoman baku bahasa isyarat Islami.

Di Malaysia, bahasa isyarat sedang diusahakan menjadi bagian dari kurikulum sekolah, mulai sekolah dasar hingga perguruan tinggi. Ada juga juru bahasa yang duduk disamping khatib untuk menterjemahkan khutbah jumat kepada kaum tuli.

Lebih lanjut, dia menjelaskan, sejumlah negara sudah sampai pada tahapan menerjemahkan Al-Qur'an ke dalam bahasa isyarat. diantaranya, Amerika Serikat, Inggris, Perancis.

Terdapat banyak media yang digunakan MTTI untuk menunjang kegiatankegiatan di MTTI. Namun ada media yang paling efektif yang digunakan yaitu dengan isyarat. Isyarat tersebut digunakan untuk berkomunikasi dan menyampaikan materi selama proses belajar mengajar di MT'TI. menurut Ustad Rama satu-satunya yang paling mudah itu isyarat. Alat komunikasi yang paling mudah untuk tunarungu yaitu isyarat, karena tuli tidak bisa mendengar harus visual, jadi satu-satunya yang bisa adalah melihat saja. Komunikasi dengan cara melihat yaitu bahasa isyarat. Komunikasi yang paling mudah, cepat dan tepat.

Selain isyarat terdapat satu media juga yang sangat membantu dalam proses tabligh di MTTI, yaitu white board. Media white board digunakan untuk memudahkan pengajar dalam setiap materi yang diajarkan. Jadi materi yang akan di sampaikan 
A. Khuzaimah, S.Sumijati, \& A. Shodiqin

di tulis terlebih dahulu di white board setelah itu dijabarkan melalui ceramah isyarat.

Komunikasi yang dilakukan oleh da'i kepada jamaahnya berbeda tergantung siapa sasaran dakwah tersebut. Karena dalam MT'TI ini sasaran dakwahnya jamaah tuli yang memiliki keterbatasan dalam mendengar. Untuk itu dalam penyampaian tablighnya MT'TI menggunakan komunikasi Nonverbal, yaitu komunikasi tanpa kata. Walaupun tanpa kata bukan berarti kita tidak bisa berkomunikasi, komunikasi ini acapkali digunakan untuk menggambarkan perasaan dan emosi. Dalam penggunaannya kita menggunakan isyarat yaitu gerakan tubuh.

Komunikasi nonverbal yang selalu digunakan kelompok Jamaah Tabligh meliuputi dua hal, yakni simbol yang tumbuh dan menempel dalam tubuh seseorang seperti memelihara jenggot, dan simbol yang berbetuk asesoris seorang muslim, seperti peci, pakaian gamis, dan parfum, serta simbol yang menunjukkan keakraban dan kebersamaan, seperti duduk bersimpub merapatkan barisan dan makan bersama dalam satu nampan dan berjabat tangan (Saepulloh, 2009: 672-674)

Kebiasaan memelihara Jenggot bagi kelompok Jamaah Tabligh merupakan implementasi kecintaannya kepada Rasulullah saw. karena rasulullah juga memeliharanya. Jenggot sebagi simbol atau identitas seorang muslim. Dengan jenggot, diharapkan sikap dan perbuatan kita terjaga dari perbuatan maksiat. Karena orang yang berjengkot akan sangat malu kalau berbuat jahat. Menurut salah seorang anggota Jamaah Tabligh, jenggot menjadi kontrol diri buat seorang muslim untuk tidak melakukan perbuatan-perbuatan yang melanggar syariat agama (Saepulloh, 2009: 672-674)

Kemudian simbol non-verbal yang berbentuk asesoris adalah peci, pakaian gamis, dan parfum. Peci yang biasa dipakai Jamaah Tabligh adalah berbentuk bulat dan lonjong. Sedangkan baju gamis adalah pakaian jubah panjang berlengan panjang biasanya berwarna putih. Pakaian ini dipakai bersama selanan panjang di atas mata kaki. Pakaian ini diyakini oleh anggota Jamaah Tabligh dapat mendukung kebersihan dan keberhasilan dakwah. Peci dan baju jubah ini, sama halnya dengan jenggot sebagai identitas muslim yang bermakna sebagai kontrol diri. Dengan memakai Peci dan baju gamis diharapkan dapat memelihara sikap dan perilakunya sesuai dengan syariat Islam. Jika, sikap dan perbuatan selaras dengan ajaran Islam, maka dakwah yang diperjuangkannya akan berjalan dengan baik. Karena dakwah tidak hanya disampaikan dengan bentuk tabligh bi al-lisan tetapi juga dengan sikap dan perbuatan yang baik dakwah bi al-amal. Jadi pakaian yang dipakai kelompok Jamaah Tabligh sebagai bentuk komunikasi dakwah nonverbal atau dakwah bi al-amal. Sedangkan memakai parfum sebagai simbol keindahan yang dapat menyegarkan tubuh dan menambah kepercayaan diri. Parfum yang digunakan kelompok Jamaah Tabligh adalah parfum tanpa alkohol. Karena parfum tanpa alkohol diharapkan suci dari segala najis yang diharamkan Allah, sebab akan dipakai untuk pakaian suci, di tempat suci masjid dan perjuangan suci yaitu berdakwah. Bahkan memakai wewangian ini pun sebagi bagian dari sunnah Rasulullah. Oleh karena itu dianjurkan bagi kaum muslimin 
untuk memakai parfuum terutama ketika hendak shalat di masjid.

Kemudian simbol nonverbal yang lain yang biasa diperlihatkan oleh Jamaah Tabligh adalah kebiasaan makan bersama dalam satu nampan dan jabatan tangan yang erat. Makan bersama dalam satu nampan sebagai tradisi kelompok jamaah untuk menunjukan kesederhanaan, kebersamaan dan keakraban. Mereka selalu makan dengan penuh khidmat, tertib, tenang dan teratur. Di samping makan dalam satu nampan sebagai simbol kesederhanaan dan keakraban. Tetapi juga lebih ekonomis dan ngirit serta tidak perlu membutuhkan alat makan yang banyak. Menurut pandangan seorang Jamaah bernama Bukhori. Kalau makan dalam satu napan rame-rame banyak keuntungan dan hikmah yang dapat kita ambil, yakni dapat memunculkan ikatan batin diantara sesama jamaah, menunjukkan sikap tawadhu (rendah hati) dan tidak sombong.

Selain itu, menurut pengakuan Munawar makan bersama seperti itu sebagai media untuk menummbuhkan kasih sayang diantara jamaah dan anggota keluarga, dan meningkatkan hubungan baik dan persaudaran

Terakhir, simbol nonverbal yang ditampilkan kelompok Jamaah Tabligh, ketika bersalaman dengan orang lain, selalu menggenggam erat-erat tangan yang disalami, sambil mengumbarkan senyum seadanya. Jabat tangan ala Jamaah Tabligh tersebut sebagi simbol ikramul muslim - memulyakan sesama muslim. Menurut pendapat salah seorang anggota jamaah, jabat tangan model iti merupakan media untuk saling mendoakan diantara sesama muslim, dan meningkatkan persaudaraan (Saepulloh, 2009: 672-674).

Sementara itu untuk menunjang keberhasilan penyampaian pesan-pesan dalam tabligh, mubaligh biasanya melakukan pendekatan-pendekatan kepada jamaah. Dalam proses komunikasi dengan jamaah mubaligh melakukan interaksi langsung dengan jamaah seperti mengajak jamaah berdialog.

Dalam penyampain agama kepada jamaah Tunarungu sebenarnya gampang-gampang susah, tergantung jamaah itu sendiri mempunyai kemampuan kuat atau tidak untuk belajar agama Islam. Biasanya MTTI memberikan contohcontoh yang mudah dipahami oleh jamaah. Walaupun jamaah di MT'TI memiliki keterbatasan fisik mereka tetap semangat salam menimba ilmu agama Islam. Mereka senang ada M'T'TI yang mewadahi mereka untuk belajar agama islam.

Hasil penelitian ini menemukan materi tabligh MTTI, metode tabligh MT'TI, dan media tabligh MT'TI terhadap jamaahnya.

\section{Materi Tabligh M'T'TI}

Keberhasilan tabligh tidak terlepas dari materi yang disampaikan oleh ustadz atau pengajarnya. Materi tabligh merupakan pesan tabligh yang disampaikan muballigh kepada muballagh. Pemilihan materi yang sesuai dengan kondisi mad'u merupakan hal penting yang harus diketahui oleh da'i sebelum melaksanakan aktifitas tablighnya. Da'i dituntut harus bisa menyesuaikan diri dengan keadaan mad'u yang akan didakwahinya. Sehingga dalam merumuskan materi tabligh dapat 
memilih manakah yang sesuai dan dapat diterima oleh mad'u dengan materi yang disampaikan nantinya.

Dalam penyusunan materi tabligh, harus ditentukan dari mana sumber materi tabligh tersebut. Dalam hal ini materi tabligh yang di sampaikan di MTTI bersumber dari Al-Qur'an dan Hadits. Jadi untuk penyusunan materi tablighnya MTTI mengkaji nilai-nilai yang terdapat dalam Al-Qur'an dan Hadits. Materi yang disampaikan di MTTI masih terbilang sederhana karena melihat kondisi jamaah tuli di MTTI ini yang masih belum mengenal agama Islam terlalu jauh, sehingga masih sulit untuk menerima materi yang terlalu berat. Materi disampaikan dengan metode majelis ta'lim dengan guna memberi ilmu agama Islam. Materi-materinya adalah: Tauhid, fiqih, mengaji Al-Qur'an, bahasa arab.

Ketika Tunarungu berkenalan dengan Tuhan. Tanpa kata, tanpa suara. Namun memiliki keinginan kuat untuk mengenal Tuhannya. Majelis Ta'lim Tuli Indonesia menjadi wadah Tunarungu untuk belajar agama. Penerjemah atau ahli bahasa isyarat menjadi perantara mereka belajar agama. Memiliki keinginan kuat belajar agama perlaham mereka sudah mengenal agamanya.

Pesan dakwah yang selalu disampaikan oleh kelompok Jamaah Tabligh, terdiri atas tiga materi pokok, yakni: "wahdaniyat, akhirat dan risalah."

Pertama, wahdaniyat diartikan sebagai pengakuan akan eksistensi KeEsaan dan Kebesaran Allah SWT. Allah adalah satu-satunya Tuhan yang kita sembah, tempat kita memohon dan bergantung kepada-Nya, "Iyyakana budu waiyya kanastain." Tiada Tuhan selain Allah, "Lailaha Illallah." Berkenaan dengan konteks ini, Allah berfirman: "Qul huwallahu ahad, Allaahu shamad, lam yalid walan yuulad, walam yakun lahuu kufuwan ahad." "Katakanlah, Dialah Allah, Yang Maha Esa, Allah tempat meminta segala sesuatu, Dia tidak beranak dan diperanakan, dan tidak ada sesuatu pun yang setara dengan Dia." Ayat ini mempertegas kepada kita bahwa Allah-lah Tuhan Yang Maha Esa. Esa dalam zat-Nya, dan Esa dalam sifat-Nya. Dengan mengakui ke-Esaan, dan kebesaran Allah SW'T, maka orang merasa bahwa kita itu kecil di hadapan Allah SWT. Dan dengan mengakui kehebatan dan kekuasaan Allah, maka kita merasa hidup ini selalu diawasi Allah. Karena merasa diawasi Allah, maka hidup kita selalu berhati-hati untuk tidak melakukan perbuatan maksiat, serta berupaya meningkatkan iman dan taqwa kepada Allah SWT (Saepulloh, 2009: 675).

Awal mula terbentuknya Yayasan MTTI masih banyak sekali jamaah tuli di MT'TI yang belum paham agama Islam itu seperti apa. Biasanya materi yang di ajarkan yaitu program-program utama untuk meningkatkan pemahaman keagamaan terhadap mereka, seperti tauhid yaitu pengenalan terhadap Tuhan.

Materi yang disampaikan seperti pengenalan terhadap Tuhan. Jadi materi yang disampaikan bertahap, mulai dari siapa Allah, ke Esaan Allah, mengapa wajib menyembah Allah, sifat-sifat Allah, macam-macam tauhid dan lain sebagainya. Karena jamaah M'T'TI awalnya banyak yang belum mengenal Allah, maka di MT'TI disampaikanlah materi Tauhid, untuk memberi pelajaran kepada jamaah tentang 
siapa Allah dan kewajiban kita terhadap Allah.

Jadi dalam materi Tauhid ini MT'TI mengajarkan tentang ketuhanan. Yang awalnya mereka tahu Tuhan itu banyak, kita kasih tahu Tuhan itu hanya Allah yang berhak disembah.

"Jadi banyak dari mereka ini walaupun sebagian solat ada juga yang sudah haji tapi konsep ketauhidannya ga paham. Allah satu juga ga paham, pahamnya Allah itu ada banyak. Allah itu laki-laki pemahaman mereka” (wawancara Ustadz Farid, pengajar di Yayasan MT'TI).

Biasanya materi fiqih yang diajarkan adalah materi dasar tentang ilmu fiqih. Materi-materi fiqih yang diajarkan anatar lain: thaharah, cara wudhu, adab-adab dll

Dalam berwudhu MTTI memberikan teori terlebih dahulu bagaimana tata caranya, urutannya dan lain sebagainya. Setelah tahu caranya baru mengajarkan ke prakteknya. Dalam mengajarkan fiqih MT'TI selalu mengajarkan yang paling umum yang biasanya diterapkan didalam kehidupan sehari-hari.

Dalam materi adab, materi yang disampaikan sesuai dengan materi yang Nabi Muhammad sampaikan kepada kita umatnya. Biasanya materi yang disampaikan lebih ke mengikuti perbuatan Nabi Muhammad SAW. seperti adab makan, minum, bertamu dan lain sebagainya. Materi yang disampaikan biasanya dari yang mulai dekat dengan kehidupan sehari-hari. Mengikuti perbuatan Nabi Muhammad SAW, seperti tata cara makan, minum, mandi wajib, sampai bertamu. Seperti pola materi yang lainnya, pola materi yang digunakan bertahap mulai dari yang paling sederhana sampai ke yang lebih rumit.

"Jadi biasanya ustad yang dateng kalau dia punya kemampuan dia bisa mengajarkan apa yang dia bisa. Kalo ustad yang dari pesantren gitu biasanya bawa kitab-kitab terus di ajarkan bagaimana adab-adab yang baik bagaimana kaya adab-adab makan, mandi wajib terus di ajarkan cara wudhu bagiamana. Diajarkan juga makan minum harusnya kaya gimana gak boleh tangan kiri harus tangan kanan terus gak boleh berdiri harus duduk, kecuali air zamzam berdiri gapapa." (Wawancara Ustadz Rama)

Dalam hal materi, akhlak merupakan materi yang sering diajarkan di MTTI. Karena akhlak adalah perilaku yang harus di miliki setiap umat muslim. Akhlak adalah budi pekerti, adat kebiasaan, perangai, muru'ah atau sesuatu yang sudah menjadi tabiat. Sedangkan secara istilah, menurut Ibn Miskawih akhlak adalah sifat yang tertanam dalam jiwa yang mendorong untuk melakukan perbuatan tanpa memerlukan pertimbangan (Sukayat, 2009: 32, 33)

Dalam hal ini belajar membaca Al-Qur'an adalah salah satu yang sulit dilakukan jamaah tuli di MTTI ini. Karena masih belum adanya bahasa isyarat Arab untuk membaca Al-Qur'an di Indonesia. Jadi untuk belajar membaca AlQur'an ini masih sangat mendasar mulai dari huruf hijaiyah.

Materi yang diajarkan pertama mengenalkan huruf hijaiyah, kedua mengajarkan isyarat huruf hijaiyah, menghafal isyarat huruf hijaiyah setelah itu baru ke surat-surat pendek. Tapi untuk isyarat Arab di MTTI belum terlalu di 
pelajari karena memang masih sulit isyarat Arab untuk di Indonesia. Jadi untuk belajar membaca Al-Qur'an hanya sebagian jamaah saja yang bisa di ajarkan yaitu jamaah yang masih bisa berbiacara. Untuk jamaah yang bisa berbicara terkadang juga mengajarkan teman-teman jamaah lainnya membaca Al-Qur'an dana sama belajar menghafalnya.

"Masih dalam tahap awal bangetlah kalau di Indonesia. Karena memang Qur'an ini macem-macem cara belajarnya. pertama untuk tuna rungu yang masih bisa bicara kita ajarkan kaya orang normal baca al-Fatihah, walaupun gak fasih yang penting dia bisa. Cara kedua mengajarkan pemahaman misalkan Allah perintahkan kamu untuk puasa, itu ayat al-Qur'annya apa surat apa, begitu. Yang ketiga menghafal huruf hijaiyah. Di Saudi sudah mulai mereka gerakan tangan abjad sesuai dengan huruf hijaiyah, tapi itu kan di Saudi ya yang dari lahir huruf arab. Kalau dikita masih susah. Dan yang ke empat, surat-surat al-Qur'an diajarkan artinya, misalkan Qul=katakanlah, Huwallah=Dia Allah. Jadi ngajarin artinya dari al-Qur'an" (Wawancara Ustadz Farid).

Untuk mengajarkan solat sendiri, kita ajarkan lebih ke gerakan dan teorinya seperti rukun solat, syarat solat, hal-hal yang membatalkan solat, sedangkan untuk bacaan solat masih belum karena memang sulit untuk mengajarkan bacaan solat kalau membaca Al-Qur'an saja belum bisa. Untuk bacaan solat sendiri jamaah tuli di M'TI masih sulit, karena keterbatasan fisik yang tidak bisa berbicara jadi sulit untuk mengajarkan bacaan-bacaan solatnya. Kecuali jamaah tuli yang bisa bicara masih bisa di ajarkan bacan-bacaan solat. Jadi dalam menjalankan solatnya pun hanya niatnya saja untuk beribadah kepada Allah.

“Baca Qur'annya itu kalau dia bisa bicara sebenernya bisa diajarin, tapi kan gak semua bisa bicara. Kalau dari kecilnya ga dibiasain ya sulit dan kita disini gak paksakan kalau dia harus bisa. Jadi bukan beban bagi mereka. Makanya solat mereka itu bagi yang gak bisa baca Qur'an yang penting hatinya inget Allah. Udah gitu aja yang penting hatinya. Jadi kaya apa yang kamu tau apa yang kamu bisa, kalau dia cuma taunya Allah. Yaudah pas solat Allah Allah aja gitu. Disini ada beberapa yang bisa bicara, jadi kita ajarin baca Al-fatihah. Bacaan solat kita bisa ajarin. Tapi jarang sekali. Sulit, karena dia juga gabisa bicara ya, kita ngecek hafalan dia juga gimana kan dianya gak bisa bicara. Jadi kita gak kasih beban mereka untuk bisa. Dan kita udah konsultasi sama ulama soal ini, terutama ulama Pakistan yang sudah pengalaman. Kata mereka gapapa, bahkan doa mereka aja bismillah semua kaya mau makan bismillah mau pergi bismillah dan selesai alhmadulillah, ya seperti itu pokoknya. Tapi kalau yang lebih cerdas dia bisa bicara kita bisa ajarin. Tapi Subhanallahnya disini pengaruh solat itu nampak banget bagi mereka walaupun solatnya cuma seperti itu." (Wawancara ustad Farid)

Belajar bahasa Arab dengan metode bahasa Arab isyarat yaitu menghafal huruf-huruf hijaiyah dengan menggunakan isyarat. Belajar bahasa Arab disini 
masih sangat dasar karena memang isyarat Arab yang masih sulit di Indonesia untuk saat ini.

Materi yang digunakan yaitu pertama memperkenalkan bahasa isyarat hijaiyah kepada jamaah, yang kedua mempraktekan isyarat huruf hijaiyah, yang kegita menghafal isyarat huruf hijaiyah dan yang terakhir mengajarkan sedikitsedikit bagaimana membaca al-Qur'an menggunakan isyarat huruf hijaiyah.

Materi merupakan salah satu unsur tabligh yang tanpa ada materi tabligh tidak bisa terlaksana. Selain materi-materi umum di atas, biasanya sebelum memulai materi diadakan pembukaan untuk memotivasi jamaah MT'TI agar selalu rajin datang ke pengajian. Menjelaskan betapa pentingnya belajar agama Islam. Dalam hal ini Ustadz Aprizah dan Ustadz Rama yang berperan sebagai motivator. Jadi biasanya mereka sebelum pengajian di mulai selama kurang lebih setengah jam memberi motivasi betapa pentingnya belajar agama dan semangat untuk datang ke pengajian.

"Bagaimana didunia kita hidup sebentar, kalau kita gak belajar agama rugi. Kita belajar agama untuk kehidupan kita yang selamat didunia dan di akhirat. Selamat dari pada kesengsaraan di akhirat. Maka kita buat komunitas kita buat ta'lim dua minggu sekali dan kita juga belajar itikaf sebulan sekali selama tiga hari. Bagaimana perbaikan iman, perbaikan amal agar tunarungu paham. Harus ikut contoh bagaimana Nabi Muhammas saw. Saya juga memberikan semangat mengajarkan sedikit-sedikit kepahaman agama Islam pas ta'lim yang dua minggu sekali itu. Dan sebelum ustad datang ataupun ustad datang tapi dibagi sesinya kira-kira setengah jam, saya atau ketua bergantian maju untuk menjelaskan agama dan maksud tujuan datang ke ta'lim itu untuk apa. Memberikan semangat untuk terus datang ke ta'lim dan belajar agama Islam. Isyarat Islam itu penting, sekarang belum dibuat kamusnya belum ada pelan-pelan nanti kita menuju ke arah sana." (Wawancara Ustadz Rama).

\section{Metode Tabligh MTTI}

Metode tabligh yang dimaksud adalah metode yang digunakan dalam penyampaian tabligh yang dilakukan seorang muballigh kepada sasaran tablighnya pada saat berlangsungnya proses tabligh. Metode tabligh bisa dilihat dari pergerakan tubuh, ucapan-ucapan atau hal-hal yang dilakukan oleh seorang muballigh. Melalui hasil observasi langsung yang dilakukan peneliti pada Yayasan MT'TI, metode tabligh yang digunakan bermacam-macam, diantaranya: khitobah, syiar dengan syariat, silaturahmi, diskusi, dan irsyad.

Khithabah jika ditinjau dari segi istilah sebagaimana diungkapkan oleh Harun Nasution, rasionalis Islam Indonesia adalah ceramah atau pidato yang mengandung penjelasan-penjelasan tentang sesuatu atau beberapa masalah yang disampaikan seseorang di hadapan sekelompok orang atau khalayak. Tabligh melalui media cetak (tulisan) disebut dengan kitabah, yaitu proses penyampaian ajaran Islam melaului bahasa tulisan bisa berupa buku, majalah, jurnal, surta kabar, 
pamflet, brosue, dan lain-lain yang berisikan pesan-pesan keislaman (Enjang dan Aliyudin, 2009: 57, 60)

Khitobah artinya ceramah. Pesan yang disampaikan mubaligh kepada mubalagh. Pesannya pun bermacam-macam sesuai kondisi mubalagh tersebut. Dalam penyampaian materi biasanya dilakukan oleh dua orang yang satu ceramah dan yang satunya menerjemahkan ke dalam bahasa isyarat. Tema ceramahnya juga masih yang sederhana, terkadang jamaah sendiri yang memilih mau tema apa. Cara tersebut adalah cara yang paling efektif yang digunakan untuk menyampaikan ilmu agama kepada jamaah tunarungu. Biasanya setelah mendengar ceramah yang disampaikan oleh ustadz selama pengajian, diadakan tanya jawab. Tanya jawabnya juga sesuai dengan materi yang disampaikan oleh ustadz tersebut.

Selain tanya jawab di MTTI juga terdapat kegiatan silaturahmi yang diadakan setiap sebulan sekali ke daerah-daerah jabodetabek. Fungsinya untuk mempererat tali persaudaraan dan bertukar fikiran serta menambah ilmu pengetahuan tentang agama Islam, karena sesungguhnya silaturahmi merupakan amal shalih yang penuh berkah, dan memberikan kepada pelakunya kebaikan didunia dan di akhirat. Silaturahmi juga bisa menjalin tali persaudaraan antar sesamanya. Betapa pentingnya menyambung silaturahmi. Bagi MTTI silaturahmi merupakan salah satu metode yang digunakan dalam kegiatan dakwahnya. Tanpa silaturahmi kegiatan pun tidak berjalan dengan baik. Ada dua cara silaturahmi yang dilakukan MTTI dalam kegiatannya. Pertama, dengan cara mendatangkan tuli muslim untuk mengikuti kegiatan di MTTI. Hal ini dilakukan untuk membantu tuli muslim yang belum mengerti apa-apa tentang agama Islam atau yang masih terkucilkan didalam masyarakat. MTTI mengajak dan merangkul mereka untuk bangkit dari kondisi tersebut dan bisa membuktikan jika kaum tuli dan orang normal lainnya sama derajatnya di mata Allah. Selanjutnya memberikan pelajaran tentang keagamaan, seperti mengajak dalam pengajian. Kedua, dengan adanya pengajian rutin yang dilakukan di MTTI. setiap dua minggu sekali MTTI mengadakan pertemuan antar jamaah dalam kegiatan pengajian. Hal ini merupakan salah satu metode silaturahmi dengan sesama jamaah. Bukan hanya sesama jamaah terkadang pengajar dan pengurus melakukan pendekatan dengan jamaah dengan cara mengobrol kepada jamaah. Itu merupakan salah satu bentuk silaturahmi yang dilakukan di MTTI selama kegiatan pengajian rutin. Maka dengan cara ini semua jajaran pengurus dan jamaah bisa berkumpul dan bersilaturahmi.

Pendekatan dakwah Jama'ah Tabligh dilakukan melalui jalur sosialkeagamaan dan pendidikan, sebagaimana yang dilakukan oleh organisasi Islam lainnya di Indonesia. Tetapi kelompok ini menggunakan metode dan teknik yang berbeda dalam pelaksanaan da'wahnya. Kalau organisasi dakwah yang lain, seperti NU, Muhammadiyah dan Persis melakukan dakwahnya berada di satu tempat secara menetap. Sedangkan Jamaah Tabligh mengirimkan orang-orang secara bergelombang dan bergantian ke kampung-kampung dan ke daerah-daerah tertentu secara nomaden atau berpindah-pindah. Begitu pula metode dan teknik 
dakwah yang diterapkan tidak hanya dengan ceramah-ceramah umum tetapi lebih spesipik bersilaturahmi mendatangi rumah-rumah penduduk untuk mengajak kebaikan, shalat berjamaah dan mencegah kemunkaran. Model dakwah ini sebuah model alternatif dari gerakan-gerakan dakwah yang ada selama ini. Sebab gerakan dakwah yang ada dipandang tidak efektif dan belum menghasilkan sesuatu yang luar biasa.

Dengan demikian, diperlukan gerakan dakwah yang berkesinambungan untuk menjangkau wilayah dakwah yang lebih luas yang dijadikan sasaran gerakan dakwah Jama'ah Tabligh, mulai dari lingkup perkampungan, desa, kota kecamatan, kabupaten-kota, profinsi sampai ke tingkat nasional, bahkan internasional.

Dengan demikian, pola dakwah yang dilakukan Jama'ah Tabligh tersebut menarik untuk dikaji secara mendalam dan komprehensif. Karena pola ini memberikan alternatif dakwah yang lebih substantif dibandingkan dengan pola dakwah/tabligh yang dilakukan oleh organisasi-organisasi dakwah lainnya (Saepulloh, 2009: 670).

Metode diskusi juga merupakan metode yang bisa menunjang keberhasilan penyampaian tabligh di MTTI. Diskusi yaitu sebuah interaksi komunikasi antara dua orang atau lebih biasanya dilakukan untuk memecahkan suatu masalah. Kegiatan diskusi di MTTI ini biasanya dilakukan untuk membicarakan sesuatu yang penting misalnya membuat program kerja di MTTI seperti program umroh. Selain itu diskusi juga digunakan untuk membicaran permasalahan-permasalah yang ada selama kegiatan di MTTT.

Irsyad merupakan penyebarluasan agama Islam yang menampilkan hungan personal antar pembimbing dan terbimbing. Irsyad dilakukan oleh dua orang indvidu atau kelompok kecil. Biasanya irsyad dilakukan oleh beberapa orang saja dan bukan kegiatan yang sering dilakukan di MTTI. di MTTI irsyad dilakukan antara jamaah dan ustadz, biasanya dilakukan pada saat kegiatan itikaf dimasjid selama tiga hari. Bertanya tentang apa yang ingin diketahui atau untuk meminta solusi atas permasalahan yang ada.

\section{Media Tabligh MTTI}

Dakwah adalah suatu aktifitas yang berorientasi pada pengembangan masyarakat muslim. Bagi Muslim dakwah berfungsi sebagai proses peningkatan kualitas keimanan dalam penerapan ajaran-ajaran agamanya. Bagi seorang da'i mengetahui dan memahami keadaan masyarakat yang menerima menjadi hal yang sangat penting agar tujuan dari dakwah bisa tercapai dengan maksimal. Objek dakwah atau yang biasa disebut sebagai mad'u secara umum adalah semua manusia, dan secara khusus salah satunya adalah mereka yang mempunyai keterbatasan.

Sama halnya dengan tabligh, tabligh juga merupakan bagian dari dakwah yaitu untuk menyampaikan ajaran-ajaran Islam kepada umat manusia. Tidak membeda-bedakan semua sama, semua berhak mendapatkan pendidikan ataupun ajaran Islam. Meskipun begitu, sampai saat ini keberadaan difabel masih terdiskriminasi, baik secara struktural maupun kultural. Perihal tersebut dapat 
dibuktikan bahwa masih banyaknya peraturan dalam sistem negara ini yang menghalangi mereka untuk memperoleh hak-hak yang sama dengan masyarakat penyediaan layanan pendidikan (Safrudin Aziz, 2014: 46-47).

Terdapat banyak media yang digunakan MTTI untuk menunjang kegiatankegiatan di MT'TI. Namun ada media yang paling efektif yang digunakan yaitu dengan isyarat. Isyarat tersebut digunakan untuk berkomunikasi dan menyampaikan materi selama proses belajar mengajar di MT'TI. menurut Ustad Rama satu-satunya yang paling mudah itu isyarat. Alat komunikasi yang paling mudah untuk tunarungu yaitu isyarat, karena tuli tidak bisa mendengar harus visual, jadi satu-satunya yang bisa adalah melihat saja. Komunikasi dengan cara melihat yaitu bahasa isyarat. Komunikasi yang paling mudah, cepat dan tepat.

Komunikasi nonverbal acapkali dipergunakan untuk menggambarkan perasaan, emosi. Jika pesan yang anda terima melalui sistem verbal tidak menunjukkan kekuatan pesan maka anda dapat menerima tanda-tanda nonverbal lainnya sebagai pendukung (Alo Liliweri, 1994: 89).

Komunikasi nonverbal juga acapkali disebut: komunikasi tanpa kata (karena tidak dapat berkata-kata (Alo Liliweri, 1994: 89). Para ahli komunikasi berpendapat bahwa jika anda diam, maka diamnya anda merupakan satu bentuk komunikasi antarpribadi. Diam juga merupakan kata-kata anda. Seseorang yang diam tidaklah sembarang diam, ia mungkin bertindak tepat (ata mungkin kurang tepat). Diam sama kuatnya dengan pesan-pesan verbal yang diucapkan dalam kata-kata. Dengan berdiam diri maka anda telah berkomunikasi secara nonverbal. Terkadang mungkin tanpa suara, tanpa kata, atau mungkin dengan gerakan tubuh/anggota tubuh, anda tetap melakukan komunikasi nonverbal. Meskipun anda berdiam diri namun pernyataan wajah anda pun bisa dengan makna tertentu terhadap pribadi dan memberikan pesan dengan orang lain (Alo Liliweri, 1994: 88).

Berdasarkan hasil analisis yang dilakukan selama penelitian di MTTI. terdapat banyak media yang digunakan MTTI untuk menunjang kegiatan-kegiatan di MT'TI. Namun ada media yang paling efektif yang digunakan yaitu dengan isyarat. Isyarat tersebut digunakan untuk berkomunikasi dan menyampaikan materi selama proses belajar mengajar di MTTI. menurut Ustad Rama satusatunya yang paling mudah itu isyarat. Alat komunikasi yang paling mudah untuk tunarungu yaitu isyarat, karena tuli tidak bisa mendengar harus visual, jadi satusatunya yang bisa adalah melihat saja. Komunikasi dengan cara melihat yaitu bahasa isyarat. Komunikasi yang paling mudah, cepat dan tepat.

Selain isyarat terdapat satu media juga yang sangat membantu dalam proses tabligh di MT'TI, yaitu white board. Media white board digunakan untuk memudahkan pengajar dalam setiap materi yang diajarkan. Jadi materi yang akan di sampaikan di tulis terlebih dahulu di white board setelah itu dijabarkan melalui ceramah isyarat. "Bahasa isyarat, satu-satunya yang paling mudah itu isyarat. alat komunikasi yang paling mudah untuk tunarungu yaitu isyarat. Tuli tidak bisa mendengar harus visual, jadi satu-satunya yang bisa adalah melihat saja. Komunikasi 
dengan cara melihat yaitu bahasa isyarat. Komunikasi yang paling mudah, cepat dan tepat." (Wawancara ustad Rama)

\section{PENUTUP}

Hasil penelitian dan pembahasan skripsi ini merujuk pada pembatasan dan rumusan masalah dapat diambil kesimpulan bahwa:

Pertama, materi tabligh yang disampaikan MTTTI kepada jamaahnya disesuaikan dengan kondisi jamaah tersebut agar mudah untuk di pahami. Klasifikasi materi yang disampaikan MTTI meliputi program-program utama, yaitu Tauhid, Fiqih, Adab-adab. Setelah penyusunan materi maka dikembangkan agar materi tersebut mudah dipahami. Seperti pada saat kegiatan ceramah Ustad di MTTI banyak mengajak jamaah MTTI untuk rajin mengaji dengan menggunakan kata-kata dan bahasa yang lembut agar dari pola materi tabligh yang telah disampaikan diharapkan jamaah MTTI dapat menambah pemahaman tentang keagamaan mereka dan bisa mengamalkannya dalam kehidupan seharihari.

Kedua, dalam metode tabligh MTTI dibagi kedalam beberapa metode, diantaranya: Metode khitobah, Syiar dengan syariat, Silaturahmi, Diskusi, dan bentuk dakwah Irsyad.

Ketiga, tabligh di MTTI terdapat beberapa media yang digunakan untuk menunjang keberhasilan proses kegiatan di MTTI. Diantara media tersebut, ada satu alat yang paling penting yaitu bahasa isyarat. Bahasa isyarat disini adalah alat untuk berkomunikasi kepada jamaah MTTI, tanpa adanya bahasa isyarat komunikasi pun sulit dilakukan. Untuk itu dalam penyampaian pesan tablighnya perlu alat yang mendukung agar tercapainya pesan tersebut. alat tersebut yaitu bahasa isyarat. walaupun banyak media yang diperlukan dalam membantu keberhasilan proses tabligh, tapi satu-satunya media yang terpenting adalah bahasa isyarat.

Hasil penelitian di MTTI, penulis ingin memberikan saran dengan Harapan dapat memberikan sumbangan positif bagi pelaksana tabligh di MTTI, yaitu: Dalam kegiatan yang dilakukan sudah termasuk dalam kategori baik. Nilai-nilai yang disampaikan kepada jamaah pun di sudah banyak diterapkan dalam kehidupan sehari-hari. Namun alangkah baiknya, lebih ditingkatkan lagi kegiatan pengajian di MTTI, bukan hanya ceramah keagamaan setiap pengajian rutin tapi juga di adakannya buku panduan untuk Tunarungu agar bisa memudahkan untuk belajar agama. Jangan pantang penyerah dalam menimba ilmu walaupun keterbatan fisik yang dimiliki. Karena belajar agama sangatlah penting untuk kehidupan di dunia dan akhirat. Bagi peneliti yang akan datang yang akan meneliti tentang MTTI diharapkan dapat menambah informasi lebih baik lagi dan menutupi kekurangan yang terdapat dalam penulisan skripsi ini.

\section{DAFTAR PUSTAKA}


A. Khuzaimah, S.Sumijati, \& A. Shodiqin

Aziz, S. (2014). Perpustakaan Rumah Difabel. Yogyakarta: Ar-Ruzz Media

Enjang dan Aliyudin. 2009. Dasar-dasar Ilmu Dakwah. Bandung: Widya Padjajaran.

Hardjana, A. M. 2007. Komunikasi Intrapersonal dan nterpersonal. Yogyakarta: Kanisius.

Kusnawan, A. 2009. Dimensi Dakwah. Bandung: Widya Padjajaran.

Liliweri, A. (1994). Komunikasi Verbal dan Non Verbal, Bandung: PT. Citra Aditya Bakti

Ma'arif, B. S. 2010. Komunikasi Dakwab: Paradigma Untuk Aksi. Bandung: Simbiosa Rekatama Media.

Saepulloh, U. (2009). Model Komunikasi Dakwah Jamaah Tabligh. Academic Journal for Homiletic Studies. Vo. 4 No. 4.32

Sukayat, T. (2009). Quantum Dakwah. Jakarta: PT Rineka Cipta 